\title{
Religious Structure of Child Education Policy in Germany, Poland and UK
}

\author{
K. Heland-Kurzak
}

\begin{abstract}
European countries differ tremendously in terms of religious education. The presence of religion in school is determined by the relationship between the state and church related. This article traces the contemporary differences in religious education in Germany, Poland and the UK. Intensive work on religious education in the UK led to compulsory religious education, but differently comprehended than the traditional teaching of religion, because it focuses on the basics of different religions and traditions. Germany with two main religions necessarily create an environment to give the young person choice in the educational process, meaning the specific nature of religious education, its scope, form and dutifulness. In Poland there are various religious communities, and they have the right to religious education, despite the fact the Polish schools are mainly of the Catholic religion, as approximately $\mathbf{8 8 \%}$ of Poles are Roman Catholic.
\end{abstract}

Index Terms - Confessional, education policy, intercultural, religious education, secularisation.

\section{INTRODUCTION}

Throughout Europe, religion in education is one of the most discussed topics in the debate about teaching in schools. Rarely have things so strongly kindled emotions. The close relationship between parents and their children, the rights and responsibilities of parents, as well as the rights of the child and, last but not least, the role of society and the state of the education of the younger generation with the function of religion in the national identity in the past and today, all these issues underline numerous skirmishes and social struggles. That the state should support religious schools is a matter of debate. The approach to equality, freedom and social cohesion dictates the method of education for all children. On the other hand, we can say that equality means creating separate religious schools. However, state support for religious freedom punishes financially supported religious schools. The Bader concept of justice implies equal treatment, in opposition to neutrality. He also claims that the idea of pluralism in the country is more suitable than the secular system based on neutrality and total domination of religious groups in education [1].

In Europe, we have to deal with a new situation, as more and more weight in the field of religion studies, dialogue and education. A good example is the research project RedCo "Religion in Education. A Contribution to Dialogue or a Factor of Conflict in Transforming Societies of European

Manuscript received March 2, 2015; revised August 18, 2015.

K. Heland-Kurzak is with the Maria Grzegorzewska Academy of Special Education, Poland (e-mail: kheland@aps.edu.pl).
Countries?" which the European Commision funded between 2006 and 2009 [2]. The main activities in Europe are going in the direction of promoting understanding and respect of different religions. The European Commission in this regard issued a White Paper on Intercultural Dialogue, Living Together As Equals in Dignity, the Council published a Recommendation in 2008. Researchers co-operated in developing a thematic and methodical approach designed to gain better insight into how European citizens of different religious, cultural and political backgrounds can live together and enter into a dialogue of mutual respect and understanding [3]-[7].

Cultural Modernization and secularization performed thorough religious education is open to the problems of society which is putting increasing emphasis on ethical issues. The abandoning of tradition and growing religious diversity due to the subject of reflection on the concepts of intercultural and interreligious education, makes it necessary to rethink its approach in relation to religion.

Empirical studies have shown that the long-term trend of secularization in European society has had an impact on the religious orientation of youth. These studies confirm that young people are moving away from institutional religion - in place of the growth of institutional religion religious faith becomes highly individualized [8], [9].

In Polish literature, this problem is dealt with mainly in the field of theology [10]-[13]. In contrast, religious education in Germany follows the direction and discipline of a recognized tradition, especially the Protestant one [14]. Polish research in education sciences is marginal, and a group of people who take this subject put it in the context of religious education [15].

\section{RELIGIOUS EDUCATION IN GERMANY}

In Germany, religious education in schools is guaranteed by the constitution and takes place in all schools, just like any other school subject. In most federal states assessment of religion is taken into account in the students progression in school. The state does not interfere in the content of education, but it allows religious education and pays teachers and control of religious education was not discriminated against. Attendance is compulsory and for students who gave up religious education. lessons in ethics were organized..

In Brandenburg they made religious studies instead of religion, but the Constitutional Court also ordered religion classes, but students may be exempted from religious studies.

The Roman Catholic and Protestant churches have roughly the same number of believers; and attract about $30 \%$ of the population. There are also several smaller religions and 
religious communities. Approximately $1.55 \%$ of people belong to Orthodox Churches. About 5\% are Muslims; $0.1 \%$ Jews. Approximately $32-37 \%$ of the population does not belong to any religion, of which the majority are in the eastern part of the country [16].

Religious education in Germany has opened itself to the multicultural education. The purpose of religious education is defined from pedagogical and theological terms. In Germany two religion communities are dominates: Catholic and Protestant. Both religion communities carrie a share of responsibility for religious education in schools. Religious communities are challenged to keep their own traditions in the context of religious and cultural diversity. In addition, contextual factors, such as the religious landscape of the region and people's faith is a strong factor in the formulation of the religious education curriculum [17].

In Germany, religious lessons go beyond the issues of church, also taking secular issues, especially social and political, interpreted in the context of faith [18]. Because these are the most common problems facing every human being, they are included within the scope of teaching religion. The political dimension of religion classes is a responsibility for the future of social and environmental. Topics relating to issues of peace, justice and environmental protection have become a challenge and task of religious education

Secularization theorists are wrong. Society does not become not religious. On the contrary, religion plays an important role in many varieties of Christianity and established churches. Secularization theory has been replaced by the paradigm of diversity. In the late 1990s, there was a discussion on whether the German society was open to multiculturalism and still needs to learn to become such a society. The task of the German society is to start respecting the presence of people from different cultural and religious backgrounds. Pluralism should be reflected in the role of religion in the education system. This creates new challenges for religious education, namely integration, communication, conflict management and diversity all of which are not easily accessible to schools (in terms of balance between dialogue and conflict in the German school). The traditional approach to religious education should be subject to review and proposals for change should be firmly drawn [5].

\section{Religious EdUCATION IN POLAND}

The content of teaching of religion of a particular denomination is decided by the competent authorities of a church or religious association. The programmess and textbooks for religious education are submitted to the Minister of Education for approval.

In Polish literature, this problem is dealt with mainly in the field of theology [10]-[13]. "Currently, there is increasing discord between Church and society, and society is demanding dynamic change and openness to having its voice heard. Traditional society is rapidly disappearing, especially within large urban communities. Deference to authority and the non-reflexive receipt of beliefs as facts are beginning not to matter. Attitudes of self-consciousness and independent choice are being developed" [19]. In the framework of dissemination of secularization, the curriculum has changed in terms of religious education with the introduction of religious studies in secondary schools.

In Poland, Catholic faith is deeply rooted in the history, traditions and culture, and accordingly it has become an inseparable element of the educational system. There are attempts to secularize and even eliminated religion from schools, but those attempts will not succeed until society will change its thinking about religion.

The Constitution of the Republic of Poland in Article 25 paragraph. 2 declares impartiality by the Polish authorities in matters of religious beliefs. Art. 53 paragraph 4 of the Constitution provides parents the right to education and religious instruction of children in accordance with their beliefs. Fourth paragraph of the same article reads as follows: "The religion of a church or other legally recognized religious organization may be taught in schools, but other peoples' freedom of religion and conscience shall not be infringed thereby" [20].

In Poland, the religious education of the Catholic Church is governed by two documents: Programme of Catholic Church catechesis in Poland and the General Directory for Catechesis. The characteristic element of the Programme of the Catholic Church catechesis in Poland should be considered to be the content of the document. It is based on the principle of the so-called duality of fidelity: fidelity to God and of fidelity to man. The notion of "the principle of fidelity" started to use the terminology of catechesis at the beginning seventies in the last century due to its subjective recognition of catechesis [21]. In this sense, the first of the catechesis is God, and second, human. In addition, this rule reminds that God - as the actors of catechesis - is also its contents. In this approach, it emphasises that any proclamation of salvation must focus on God's saving initiatives, His concept of man and the desire to fullfill him with the gift of happiness. Therefore, the principle dual fidelity assumptions appropriate to speak about the second actor catechesis - Man should refer to the relationship with the God. Is explained by the fact that catechesis aims to uncoverito man the meaning of his relationship with God, as the effect should be acquiring the gift of divine life, which teaches His thinking, acting and love [22], [23].

Research conducted by Pawlik, confirms that the choice of religion classes by students is caused by a conformist attitude. Students when asked why they participate in religion, replied that they do not want get in trouble by the lack of evaluation certificate ( 24 percent.), 18 percent comes from habit, 10 percent attend, "because the others go." One-fifth of the students admit that the decision was made without their participation, and in some cases had been forced by their parents. In addition, it is important that participation in such classes is appreciated by educators - answered 17 percent of the surveyed students [24]. Teaching religion in schools is in crisis. Secondary school students, in the period of exploration and rebellion do not accept the simple religious message, which appeared in elementary school. Young people demand something else - debate, discussion, more attractive formula based on the experience resulting not only from the Catholic religion. There is always the other side is prepared for this, there is often a conflict between students and the teacher.

According to Milerski religious education should recognize the secular state and its institutions. It is assumed 
that in a secular state public institutions are committed to equal treatment of citizens, regardless of their beliefs. The role of these institutions is to guarantee people freedom of conscience and faith - the feasibility of such freedom and at the same time protect them against indoctrination of others. Therefore they should create conditions that no citizen is exposed, for example, in a public school, to discrimination in a religious sense. The ideological neutrality principle, in its radical form, is that the role of the state does not support any religion, and is moderate - to determine a permissible forms of cooperation state - the church (religion), provided, however, that it will be possible, subject to all legally recognized religion. This treatment allows the exploration of the presence of religious education in school education [15].

Religious education in Polish schools, can now be seen in the context of, aimed primarily educative and religious aspirations, which are included in the curriculum, implemented religion classes in schools. The first years based on the introduction of the sacrament of Penance and the Eucharist and the Church explicitly introduces the category of learning rather than fun: at this stage of development the child goes from playgroup activity for learning [25]. Religiousness from the catechesis side is reduced to the knowledge, depriving their experiences and organize their own religion by a child. This process clearly shows the phrase, "for children in first and second grades, the process of learnings attractive, and meet the requirements of the teacher and work with didactic materials". This statement condenses the Religion teacher requirements as formulated in the teaching material. Contemporary catechesis is mainly based on religious concepts requiring memory, and ignores the creative nature of children, "at this age, it is the development of sensations and perceptions, memory and speech development. Development experiences and insights discern details on content that previously were regarded in the mind of the child. Fun ceases to be the dominant element of activity" [25]. Creation reflective attitude towards religion is obscured content to memory doctrine of assimilation. Inspiring and motivating children to religious thinking is brought to the knowledge, and the emotional nature of the child's experience is dominated by "proclaimed adherence to the content" [25].

\section{RELIGIOUS EDUCATION IN UK}

The concept of religious classes in English, based on the Multi-faith Approach, "information" rather than a "formation", responds to the need to know the different religions that exist in a pluralistic society (religious social aspect). However they do not talk about religious studies, but rather still about religious education. Religious Education in England and Wales in recent years is seen as a promoter of social cohesion and good social relations, as evidenced by the Law on Education and Inspection Act in 2006. Control of education also rests with Ofsted, who in 2013, issued a report on RE. Religious education (RE) should significantly contribute to the education of children and youth. At its best, it is intellectually challenging and personally enriching. It helps young people develop beliefs and values, and promotes the virtues of respect and empathy, which are important in our diverse society. It promotes civilized debate and reasoned argument, and helps students to understand the place of religion and faith in the modern world [26]. RE then, is seen as an effective vehicle for the promotion of the "British Values" [27] of "democracy; rule of law; individual liberty; mutual respect and tolerance of other people's faiths and beliefs' as set out in the Government's Prevent, counter-terrorism strategy. The link between RE and counter-terrorism is seen most clearly in the Government funded Resilience project. This Government funded programmes, led by the RE, trains RE teachers in dealing with belief-based extremism and related contentious issues [28].

In the UK, Catholic schools, Church of England, Jewish schools became a mandatory part of education. The purpose of religious education is not the teaching of one religion, because it includes many denominations, although the legislation contains mostly Christian content. In Scotland, religious education is a religiosity and its purpose is to present Christianity in the context of the search for the meaning of life. In Scotland, there are two programmes of religious education: Religious and moral education. Principles and practice and Religious education in Roman Catholic schools. Principles and practice [29], [30].

The first programme is religious education and moral development of children's understanding of Christianity that shaped the history and tradition of Scotland. During the planning of religious and moral education, schools take account of the communities in which children and young people learn and live. Taking part in the religious and moral education, all children and young people can develop an understanding of Christianity, which has shaped the history and traditions of Scotland and still have an impact on national life.

The second programme "Religious education in Roman Catholic schools". Principles and practice. Religious education in schools is the responsibility of Catholic religious Education Committee acting on behalf of the Bishops' Conference of Scotland. In Catholic schools, the term "religious education" is used instead of "religious and moral education". "Religious education in Catholic schools takes place within the context of the wider Catholic faith, in partnership with home and parish. It is an integral part of the Catholic school, which is itself a community of faith. It is designed to assist children and young people to be increasingly able to make an informed and mature response to God in faith and to nurture that faith. It offers opportunities for both evangelization - proclaiming the Gospel message to all - and catechesis - the deepening of existing faith commitments among believers" [29], [30].

Religious Education is a compulsory subject for all students under 16 years of age. These are the activities of religious studies, primarily based on Christianity, but without favoring any religion. Lessons are based on religionology, not theology. There will be common, school prayer, but not associated with only one confession or religion, though largely Christian. It also involves obligatory daily prayer. Parents may decide that their child will not be attending religious education. The content of religious education is the great religions, among which Christianity is granted more attention. The specific programmes are developed by local education authorities (LEA). This model was accepted 
positively by teachers, students and parents. Religious Education represents individual religions referring to the personal development of the content of the students. Where possible, the issues are presented in an objective and neutral view of the world in the light of questions about the truth. Added to this is the personal conviction of a teacher, which, however, should not be more important in the classroom. The teacher does not have to be a believer. This solution is favored. "Birmingham school" and its leading representative - JM Hull. According to these assumptions, the Bible can not be read in a secular school as a "holy book", but must be in relation to the different experiences of the student. The Bible is not interpreted as a document of faith, but as an educational book [31]

A study published in 2012, reflects the quality of support for religious education in England and Wales. More than half of respondents (53\%) believe that RE should continue to be a mandatory subject. The study was conducted by YouGov on behalf of the Religious Education Council of England and Wales (REC):

1) "Over half (53\%) of all adults in England and Wales RE think that it should remain 'a compulsory subject in state funded schools

2) $58 \%$ think it is beneficial for pupils to study RE

3) The above two Percentages rise to $63 \%$ in each case among 18-24 year olds

4) 1 in 2 adults think RE A provides a valuable space in the school day the where young people can learn about all religious and non-religious beliefs". The respondents are of the opinion that the RE is an essential component of a multi-faith society, because it promotes mutual respect, tolerance and understanding of others. In contrast, only $9 \%$ said they thought it was 'harmful' for pupils to study RE and only $13 \%$ thought it should not be taught in schools at all [32], [33].

\section{CONCLUSION}

In many European countries, religious education in school is understood differently. School education system can perform its founding in different ways, depending on the concept of the state and future of the whole system of education as:

1) Separating religious education (confessional model);

2) Dialogical religious education (confessional model, open to pedagogical dialogue, ecumenical and worldview);

3) Integration formal religious education (interreligious model);

4) Integration religious education (ecumenical model). Religion and attitudes towards it is one of the determinants differentiating a multicultural society and the relationships between representatives of different religions and confessions [34].

For a long time we are witnessing a crisis of religion in schools. The crisis of religion is reflected primarily in a fall of people declaring themselves as believers. Reasons for this lie in the post-modern, individualistic and pluralistic mentality. Crisis of faith manifests itself in symptoms such as:

1) Focus exclusively on the needs of life worldly

2) Indifference to religion

\section{3) Religion is seen as unhelpful in solving problems}

Despite the crisis of religion a lot of attention is attached to the positive symptoms. Crisis in school religion classes does not mean loss. Religion must interpret human existence over and over again [13].

In Poland, the religious education is optional, organized at the request of parents or students. Teachers are paid for by the state. The church exercises substantive control and teaches pedagogical supervision. Evaluation of religious education is included in a pupils certificate but has no effect on promotion to the next class, whereas, in Germany, attendance religious classes is obligatory, and the grade of the certificate in most federal states is taken into account when promoting students to the next grade. For students who resigned from religious classes they must then take part in ethics classes. The situation looks different in England and Wales - religious education is obligatory but supradenominational - this is the transference of knowledge about religions.

Denominational religious education and religious education in public schools across Europe is not run by the state, but when it comes to teaching content it is the responsibility of the religious communities concerned. Separation of state and religion is the basic concept behind the overall system of religious education in public schools. State and ecclesiastical authorities cooperate in the conduct of religious education - the responsibility of the State to ensure that the learning takes place, the religious community is responsible for this, The State is therefore responsible for the existence of religious education and religious communities for the religious content of the curriculum. Such a system of cooperation can be considered as a clear manifestation of the strict separation of church and state.

Cultural and religious diversity are experienced in every country. No state is homogeneous culturally. Some countries have well-established ethnic and religious minorities, often with very long histories, sometimes preceding the formation of the state. Many states have such minorities as a result of migration from other countries within Europe and beyond, mainly during the 20th and current centuries. Diversity within states is complex and connects with global as well as regional, national and local issues. All of these factors are associated with an increasing view that religion and belief are not purely private issues and should be part of discussion and dialogue within the public sphere [35], [36].

The issue of teaching about religion remains a politically sensitive issue in most countries, for historical reasons, which are specific to each country and the fear of all forms of fundamentalism and extremism, particularly religious. Therefore it is important that the teaching of religion (non-confessional) and other beliefs should not be designed and delivered in isolation, but as part of intercultural education of young people. Only under these conditions will be acceptable to all, so that the school will remain peaceful world where learning takes place in a peaceful atmosphere, open to diversity and respect for all religions and other beliefs. The school can not be a place of religious confrontation; This is a place for dialogue and building intercultural experience and knowledge. More teaching about religions and other beliefs have a clear place in the school curriculum in terms of approach and content, the less it will tend to be locked in a 
strictly religious logic that has no place in a public school, and what will be in the opposite direction in the implementation of productive aims and objectives of the school.

\section{REFERENCES}

[1] V. Bader, Secularism or Democracy? Associational Governance of Religious Diversity, Amsterdam: Amsterdam University Press, 2007.

[2] M. Shaw. (2015). Beyond RE: Engaging with Lived Diversity - the role of Intercultural Education in schools. [Online]. Available: http://www.redco.uni-hamburg.de/cosmea/core/corebase/mediabase/a wr/redco/research_findings/REDCo_exhibition.pdf

[3] A. Alvarez Veinguer, G. Dietz, D.-P. Jozsa, and T. Knauth, Islam in Education in European Countries - Pedagogical Concepts and Empirical Findings, Waxmann 2009.

[4] R. Jackson, S. Miedema, W. Weiise, and J.-P. Willaime, Religion and Education in Europe: Developments, Contexts and Debates, Waxmann, 2007.

[5] T. Knauth, "Religious education in Germany: A contribution to dialogue or source of conflict? Historical and contextual analysis of the development science the 1960s," Religion and Education in Europe: Developments, Context and Debates, Waxmann: Münster, 2007.

[6] P. Valk, G. Bertram-Troost, M. Friederici, and C. Béraud, "Teenagers perspectives on the Role of Religion in their lives, school and societies. A European quantitative study," Waxmann, 2009.

[7] W. Weisse, "The European research project on religion and education 'REDCo'. An introduction," Religion and Education in Europe: Developments, Contexts and Debates, Waxmann, 2007.

[8] D. Baacke, U. Sander, and U. Vollbrecht, "Lebensgeschichten sind Mediengeschichten," Opladen, 1990.

[9] H. Barz, "Postmoderne Religion: Am Beispiel der jungen Generation in den Neuen Bundesländern," Opladen, 1992.

[10] J. Bagrowicz, Religious Education of Contemporary Youth. Sources and Destinations, UMK: Toruń, 2000.

[11] W. Kubik, Catechetical Teaching Outline, Krakow, 1990.

[12] C. Rogowski, "Hermeneutic and didactic dimension symbol of religious and pedagogical implications. Interdisciplinary study religious pedagogical dimension," Lublin, 1999.

[13] C. Rogowski, Religious Educations. Assumptions - Conditions Development Prospects, Lublin, 2002.

[14] C. Grethlein, Didactic of Religious Education. Protestant Religious Instruction in Study and Practice, Vandenhoeck \& Ruprecht, Göttingen, 2005.

[15] B. Milerski, "Pedagogical hermeneutics," Perspectives of Religious Education, ChAT: Warsaw, 2011.

[16] H. Lutter. (July 2010). Regionales monitoring 2010. [Online]. Available:

http://www.deutsche-metropolregionen.org/fileadmin/ikm/01_monito ring/IKM_Monitoring2010.pdf

[17] H. G. Heimbrock, „Religious instruction in the context of Europe. Introduction to didactic religious education in Germany," Verlag W. Kohlhammer, Stuttgart, 2004.

[18] A. Lorscheider, "The social dimension of catechesis," September 1981.

[19] K. Heland, "Non-reflexivity and the religious preparation of children in the process of socialisation", International Journal of Pedagogy, Innovation and New Technologies, no. 1, October 2014.

[20] The Constitution of the Republic of Poland, p. 4, 1997.

[21] R. Murawski, "Catechesis faithful to God and man," Catechesis, no. 5, p. 196, May 1974.

[22] Z. Marek, "The program assumptions teaching religious education in schools," Catechesis Language, Tarnow, 2008, pp. 7-12.
[23] T. Panuś, "The principle of faithfulness to God and man and its implementation in the Polish catechism. Study in the light of the Framework Programme for catechesis functioning in the years 1971-2001," Krakow, 2001.

[24] W. Pawlik, K. Kicińśki, and K. Kołesa, School or Parish? Teaching Religious Education in Schools in View of Sociological Research, Krakow, 1995.

Polish Episcopal Conference. (March 2010). The core curriculum catechism of the Catholic Church in Poland. [Online]. Available: http://www.katecheza.episkopat.pl/index.php/menu/nauczanie-religiiw-szkole/dokumenty-koscielne/32-podstawa-programowa-2010

[25] Ofsted. (2013). Religious education: Realising the potential. [Online]. Available:

http://www.ofsted.gov.uk/resources/religious-education-realising-pote ntial

[26] British Values. (2011). UK Government's Prevent Strategy. [Online]. Available:

https://www.gov.uk/government/uploads/system/uploads/attachment_ data/file/97976/prevent-strategy-review.pdf

[27] M. Shaw, "Religious education and religious literacy," The Future of Education and Society through the Eyes of Social Researchers, Warsaw, 2014.

[28] Principles and practice: Religious education in Roman Catholic schools. (2009). Scottish Government. [Online]. Available: http://www.educationscotland.gov.uk/learningteachingandassessment /curriculumareas/rme/rerc/principlesandpractice/index.asp

[29] Religious and moral education. Principles and practice. (2009) Scottish Government. [Online]. Available: http://www.educationscotland.gov.uk/learningteachingandassessment /curriculumareas/rme/nondenominational/principlesandpractice/index .asp

[30] J. M. Hull, New Directions in Religious Education, Lewes, Sussex: Falmer Press, 1982.

[31] J. Keast. (June 2012). RE for good - wide public support for RE in schools. [Online]. Available: http://religiouseducationcouncil.org.uk/public-engagement/media-rele ases/re-for-good-wide-public-support-for-re-in-schools

[32] L. J. Francis, W. K. Kay, and W. S. Campbell, "Research in religious education," Leominster/Macon, Gracewing/Smyth \& Helwys Publishing Inc, 1996.

[33] A. Różańska, "Religious education and intercultural education in a public school in a multicultural society," The Role of Religion in Intercultural Education, Krakow, 2008.

[34] Council of Europe. (August 2014). Signposts - Policy and practice for teaching about religions and non-religious world views in intercultural education. [Online]. Available: http://ww3.wandsworth.gov.uk/moderngov/documents/s34443/978-9 2-871-7966-1.pdf

[35] R. Jackson, Signposts': Policy and Practice for Teaching about Religions and Non-religious Worldviews in Intercultural Education, Strasbourg: Council of Europe Publishing, 2014.

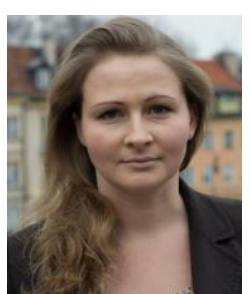

Krystyna Heland-Kurzak was born in Jastrzebia Gora, Poland. She is a PhD student and a lecturer on the Maria Grzegorzewska Academy of Special Education in field of educational sciences. She is a teacher in a kindergarten. Her research interests include religious education and social education. Her $\mathrm{PhD}$ thesis is based on pedagogical of religious education. 